\title{
INFLUENCE OF STRATEGIC FACTORS IN INCREASING STRUCTURAL GROUP ENGAGEMENT AND IMPLEMENTATION SUCCESS OF THE GREEN SUPPLY CHAIN MANAGEMENT
}

\author{
Gunawardana Vinyaman \\ Ph.D scholar, Post Graduate School of Economics \\ Hasanuddin University \\ South Sulawesi, Indonesia \\ Nurdin Brasit \\ Professor of Economics, Post Graduate School of Economics \\ Hasanuddin University \\ South Sulawesi, Indonesia \\ Mahlia Muis \\ Professor of Economics, Post Graduate School of Economics \\ Hasanuddin University \\ South Sulawesi, Indonesia \\ Muhammad Idrus Taba \\ Ph.D of Economics, Post Graduate School of Economics \\ Hasanuddin University \\ South Sulawesi, Indonesia \\ DOI: 10.31364/SCIRJ/v7.i2.2019.P0219616 \\ http://dx.doi.org/10.31364/SCIRJ/v7.i2.2019.P0219616
}

\begin{abstract}
Environmental problems have become a global issue, so the industry realizes that to evaluate the process of procurement of raw materials, distribution, customers, and stages of disposal, holistic changes are needed. This study aims to determine and analyze the influence of technological characteristics, organizational encouragement, and the quality of collaboration on the structural group engagement and GSCM implementation. Analyze the influence of the structural group engagement on GSCM implementation. This research was conducted with a quantitative approach that developed and tested the model. The research was conducted at PT Vale Indonesia (PTVI), Soroako, South Sulawesi, and PT Agincourt Resources (PTAR), South Tapanuli Regency, North Sumatra. The population and sample of the study were all leaders at various structural levels within PT Vale Indonesia (PTVI) and PT Agincourt Resources (PTAR). Methods of collecting data using a questionnaire, which was designed in the form of a closed questionnaire. The data analysis technique uses Structural Equation Modeling. The results showed that the technological characteristics and organizational encouragement variables significantly influence the structural group engagement and GSCM implementation. The quality of collaboration has a significant effect on GSCM implementation. The involvement of the structural group engagement has a significant effect on GSCM implementation. The quality of collaboration does not significantly influence the structural group engagement.
\end{abstract}

Index Terms - technological characteristics, organizational encouragement, quality of collaboration, and green supply chain management 


\section{INTRODUCTION}

Industrial development that includes business activities and operations has brought a large contribution to science and management research. One form of industrial development related to business activities and operations and has become a concern for all practitioners and academics throughout the world, namely the change (transformation) of the concept of supply chain management into a green supply chain management. The transformation was motivated by the concerns of all parties regarding the level of environmental damage that was increasingly alarming.

Government pressure and global demand trends have caused many companies to adopt GSCM (Chin et al. 2015). Changes in demand from consumers have encouraged the industry to put forward sustainable performance aspects through the application of GSCM (Singh \& Trivedi, 2016; Solomon et al. 2014; and Kafa et al. 2013). The logical consequence of the implementation of sustainable, it is necessary to identify the activities in the supply chain process that have negative potential for the environment in order to be evaluated through the design and production processes that are environmentally friendly.

Seman et al. (2012) explain GSCM's advantages for the company, namely as an effort to maintain excellence and be able to increase business profits and expand market share. The next advantage of GSCM is being able to increase energy accessibility, and increase renewable energy conversion (Halldorsson \& Svanberg, 2013). Research findings Fang \& Zhang (2018) using a metaanalysis that internal and external GSCM practices have a positive effect on corporate performance and environmental performance.

GSCM is one of the concepts that brings positive changes to environmental sustainability, but on the other hand many companies experience obstacles and obstacles when implementing GSCM. Various obstacles have been explained in detail in the study of Luthra et al (2011), the first obstacle from the perspective of cost pressure where companies implementing GSCM must bear enormous costs, this is different from conventional supply chain management which actually has costs relatively low. The second obstacle is from the perspective of flexibility, where companies implementing GSCM experience low flexibility, in contrast to conventional supply chain management which results in high flexibility.

Supply chain management activities play a role in managing products from exploration to extraction so that the values obtained can be maximized (Bice, 2011). The supply chain activities themselves, especially transportation, have an effect on the environment. This effect mainly occurs in the form of air pollution due to pollutant gas production and particulate matter, as well as the increased risk of transportation accidents (Mallidis and Vlachos, 2010). In addition, warehouses are also an important component of the supply chain. Pesch et al (2012) found that the presence of warehouses changed land that absorbs water into asphalt-covered land and cement that is not water-resistant, resulting in problems with soil erosion and loss of biodiversity.

The construction of mining infrastructure and its supply chain risks increasing hunting and deforestation in remote areas as well as large numbers of labor migration and customary agrarian issues (Levashova et al, 2010: 13, 32). Indeed, supply chain management does not consider environmental issues. This is reasonable considering that the supply chain applies generally to various companies and many industries are located in urban areas. This will be more difficult for a mining company located in a remote location, where the environment can have a major impact in providing the right quantity, right location and appropriate time. This study aims to analyze the influence of technological characteristics, organizational motivation, and the quality of collaboration on the involvement of the position structure group and GSCM implementation.

\section{LITERATURE REVIEW}

\subsection{Technological Characteristics}

The concept of green technology comes from UN enda 21 at the 1992 United Nations Environment and Development Conference (UNCED). This concept is further developed by UNESCO with an emphasis on aspects of environmental protection, ecological returns, efficiency improvements, and economic development (Wang et al. 2012). The point is that green technology aims to mitigate or reverse the effects of human activities, including mining, on the environment (Oxford Dictionary, 2013).

GSCM relies on green technology infrastructure to build a reverse supply chain and expand traditional supply chains, and produce closed loops on supplies to meet sustainability criteria (Li, 2011). Lin and Ho's (2008) study found that the exploitation and accumulation of green technology had a significant effect on the willingness of a company to adopt GSCM. Therefore, the government in Taiwan seeks to help companies overcome green technology problems so that the entire supply chain in Taiwan belongs to GSCM (Hu and Hsu, 2010). Consumers who are increasingly aware of sustainable development also try to encourage companies to develop green products and use green technology in the production process (Tseng, 2011).

\subsection{Organizational Encouragement}

Encouragement is usually seen as a form of providing support for an activity (Pullig et al, 2002). Even so, equating encouragement with support is a mistake because the concept of support relates to an activity that is driven by employee initiative, 
while encouragement is related to activities that are driven by the company's own initiatives. Encouragement can be interpreted as a form of support insofar as it is stated explicitly that the support is carried out for the actions ordered by the company.

Organizational encouragement can be expressed as "managerial support and autonomy given to groups of employees that enable them to carry out a task" (Kock et al, 2015). By stating that the activity carried out is a task, it is clear that the activity is initiated by the company, not by employees. Furthermore, the placement of autonomy as one of the elements of encouragement emphasizes that there is a wide enough free space for employees to produce various actions that can be classified as efforts to carry out tasks.

\subsection{Quality of Collaboration}

The supply chain system contains elements of collaboration because it involves a number of entities that work together to achieve common goals. This also applies to GSCM. Therefore, the concept of quality collaboration needs to be raised. Bhatti et al (2011) defines collaboration quality as "the ability of the system to allow collaboration between employees or members of a project to do a task collectively." Heimeriks and Schreiner (2002) do not see the quality of collaboration on the system that allows collaboration to occur, but in terms of the characteristics of the collaboration itself. Heimeriks and Schreiner (2002: 9) define the quality of collaboration as a specific characteristic of an alliance that has a significant positive effect on the performance of the alliance. Understood in the context of the supply chain, this definition means that the quality of collaboration is a specific characteristic of the supply chain that has a significant positive effect on the performance of the supply chain.

\subsection{Structural Group Engagement}

Engagement is an important concept because it has the potential to have an impact on attitudes towards a job and its behavior towards decision making (Josiam et al, 1999). Engagement is interpreted in various senses. One understanding of involvement is "the perception of one's relevance to an object based on inherent needs, values and interests". Other definitions mean involvement as a level of importance, emphasizing the importance of an object in an individual, or the centrality of an object in an individual ego structure. The point is that engagement is a view of the relationship between an event or an object and the structure of values, needs, and interests of a person.

\subsection{GSCM Implementation}

Research Chan et al (2012) found that three GSCM practices are influenced by the orientation of the internal environment. The orientation of the external environment such as the influence of the environment on the business and the pressures of external stakeholders on the company to organize GSCM were also tested but only affected the two GSCM practices. The external environment orientation has no effect on investment recovery. Based on these findings, it can be said that the orientation of the internal environment is more important for GSCM practices than the orientation of the external environment. The orientation of the internal environment reflects that the organization organizes GSCM with its own motivation and pressure from within itself. Therefore, internal environment orientation indicators are better able to capture GSCM implementation than external environment orientation.

\section{RESEARCH METHODS}

This research design is carried out with a quantitative approach that develops and tests models that are built on grand theory. This study examines and analyzes the variables that affect the implementation of GSCM, these variables are the technological characteristics, organizational encouragement, quality of collaboration and structural group engagement. The research was conducted at PT Vale Indonesia and PT Agincourt Resources. The research population is all leaders at various structural levels within the company. The population in this study also became a research sample (sampling census). In this study, primary data was obtained from the results of questionnaires distributed to all respondents. Methods of collecting data using a questionnaire, which was designed in the form of a closed questionnaire. Closed questionnaires were used to measure respondents' perceptions of the technological characteristics, organizational encouragement, quality of collaboration, structural group engagement and GSCM implementation. The data analysis method used in this study is descriptive analysis and multivariate statistics, namely Structural Equation Modeling (SEM). 


\section{RESULTS AND DISCUSSION}

\subsection{Research Instrument Testing Results}

The results of testing this research instrument are described based on each variable, the results of the instrument test are presented as follows.

Table 1

Validity Test Results of Each Construct: the Technological Characteristics

\begin{tabular}{lcccc}
\hline \multicolumn{1}{c}{ Indicator } & $\begin{array}{c}\text { Scale Mean if } \\
\text { Item Deleted }\end{array}$ & $\begin{array}{c}\text { Scale Variance if } \\
\text { Item Deleted }\end{array}$ & $\begin{array}{c}\text { Corrected Item- } \\
\text { Total } \\
\text { Correlation }\end{array}$ & $\begin{array}{c}\text { Cronbach's } \\
\text { Alpha if Item } \\
\text { Deleted }\end{array}$ \\
\hline T1 - Green technology in the office & 11.8936 & 4.449 & 0.554 & 0.755 \\
T2 - Green technology in the field & 11.8404 & 3.942 & 0.664 & 0.698 \\
T3 - Green technology replaces old & 11.9202 & 4.127 & 0.601 & 0.732 \\
$\begin{array}{l}\text { technology } \\
\text { T4 - More and more green technology }\end{array}$ & 11.7713 & 4.530 & 0.563 & 0.751 \\
\hline
\end{tabular}

Based on the results seen in Table 1, it can be seen that the value of $r$ count $>r$ table value at $\mathrm{df}(144-2)=0.137$, the value is higher than the entire value of the corrected item-total correlation. Thus, it can be stated that all the questions on the T1 indicator, T2, $\mathrm{T} 3$, and T4 valid or able to express the value of the validity measured by the questionnaire. The next stage is outlined the results of the validity analysis on the organizational encouragement variable as follows.

Table 2

Test Results for the Validity of Each Construct: the Organizational Encouragement

\begin{tabular}{lcccc}
\hline \multicolumn{1}{c}{ Indicator } & $\begin{array}{c}\text { Scale Mean if Item } \\
\text { Deleted }\end{array}$ & $\begin{array}{c}\text { Scale Variance if } \\
\text { Item Deleted }\end{array}$ & $\begin{array}{c}\text { Corrected Item- } \\
\text { Total Correlation }\end{array}$ & $\begin{array}{c}\text { Cronbach's Alpha } \\
\text { if Item Deleted }\end{array}$ \\
\hline O1 - Direct order & 26.8085 & 20.562 & 0.288 & 0.764 \\
O2 - Fund support & 26.8511 & 18.373 & 0.478 & 0.735 \\
O3 - Provision of motivation & 26.9894 & 17.583 & 0.562 & 0.719 \\
O4 - Support facilities & 26.9255 & 17.973 & 0.555 & 0.721 \\
O5 - Freedom of initiative & 26.8883 & 18.784 & 0.509 & 0.731 \\
O6 - Guide or manual & 26.9043 & 18.194 & 0.514 & 0.729 \\
O7 - Training & 26.9894 & 18.235 & 0.429 & 0.745 \\
O8 - Incentives or bonuses & 27.0426 & 18.586 & 0.372 & 0.756 \\
\hline
\end{tabular}

Based on the results seen in Table 2, it can be seen that the value of $r$ count $>r$ table value at $\mathrm{df}(144-2)=0.137$, the value is higher than the entire value of the corrected item-total correlation. Thus, it can be stated that all questions on $\mathrm{O} 1$ indicators, $\mathrm{O} 2, \mathrm{O} 3$, $\mathrm{O} 4, \mathrm{O} 5, \mathrm{O} 6, \mathrm{O} 7$, and $\mathrm{O} 8$ are all valid or able to express the value of the validity measured by the questionnaire, so that it can be used for further analysis. The next stage describes the results of the validity analysis on the quality of collaboration variables as follows.

Table 3

Test Results for the Validity of Each Construct: the Quality of Collaboration

\begin{tabular}{lcccc}
\hline \multicolumn{1}{c}{ Indicator } & $\begin{array}{c}\text { Scale Mean if } \\
\text { Item Deleted }\end{array}$ & $\begin{array}{c}\text { Scale Variance if } \\
\text { Item Deleted }\end{array}$ & $\begin{array}{c}\text { Corrected Item- } \\
\text { Total } \\
\text { Correlation }\end{array}$ & $\begin{array}{c}\text { Cronbach's } \\
\text { Alpha if Item } \\
\text { Deleted }\end{array}$ \\
\hline C1 - Help each other & 16.8617 & 18.109 & 0.549 & 0.632 \\
C2 - Conformity & 17.0851 & 17.854 & 0.535 & 0.636 \\
C3 - Coordination & 16.9415 & 17.670 & 0.539 & 0.634 \\
C4 - Trust each other & 16.8511 & 18.074 & 0.487 & 0.653 \\
C5 - Commitment & 16.0585 & 22.398 & 0.320 & 0.701 \\
C6 - Communication & 16.1755 & 22.937 & 0.201 & 0.731 \\
\hline
\end{tabular}


Based on the results seen in Table 3, it can be seen that the value of $r$ count $>r$ table value at df $(144-2)=0.137$, the value is higher than the entire value of the corrected item-total correlation. Thus, it can be stated that all questions on indicators $\mathrm{C} 1$, $\mathrm{C} 2$, $\mathrm{C} 3$, $\mathrm{C} 4, \mathrm{C} 5$, and $\mathrm{C} 6$ are valid or able to express the value of the validity measured by the questionnaire, so that it can be used for further analysis. The next stage outlines the results of the analysis of validity on the variable structural group engagement as follows.

Table 4

Test Results for the Validity of Each Construct: the structural group engagement

\begin{tabular}{lcccc}
\hline \multicolumn{1}{c}{ Indicator } & $\begin{array}{c}\text { Scale Mean if Item Scale Variance if } \\
\text { Deleted }\end{array}$ & $\begin{array}{c}\text { Corrected Item- } \\
\text { Item Deleted } \\
\text { Total Correlation }\end{array}$ & $\begin{array}{c}\text { Cronbach's Alpha } \\
\text { if Item Deleted }\end{array}$ \\
\hline I1 - Be positive & 15.6277 & 10.075 & 0.442 & 0.760 \\
I2 - Looks important & 15.5957 & 9.868 & 0.537 & 0.725 \\
I3 - Carry out the task well & 15.6489 & 9.748 & 0.576 & 0.712 \\
I4 - Initiative without being told & 15.6436 & 9.439 & 0.603 & 0.702 \\
I5 - Participation in submitting & 15.5691 & 9.851 & 0.536 & 0.725 \\
ideas & & & & 0 \\
\hline
\end{tabular}

Based on the results seen in Table 4, it can be seen that the value of $r$ count $>r$ table value at df $(144-2)=0.137$, the value is higher than the entire value of the corrected item-total correlation. Thus, it can be stated that all questions on indicators I1, I2, I3, I4, and 5 are valid or able to express the value of the validity measured by the questionnaire, so that it can be used for further analysis. The next stage describes the results of the validity analysis on the GSCM implementation variables as follows.

Table 5

Test Results for the Validity of Each Construct: the GSCM implementation

\begin{tabular}{lcccc}
\hline \multicolumn{1}{c}{ Indikator } & $\begin{array}{c}\text { Scale Mean if } \\
\text { Item Deleted }\end{array}$ & $\begin{array}{c}\text { Scale Variance if } \\
\text { Item Deleted }\end{array}$ & $\begin{array}{c}\text { Corrected Item- } \\
\text { Total Correlation }\end{array}$ & $\begin{array}{c}\text { Cronbach's Alpha } \\
\text { if Item Deleted }\end{array}$ \\
\hline S1 - Concentrated efforts & 15.7181 & 9.958 & 0.278 & 0.844 \\
S2 - Policy / SOP & 15.5798 & 8.395 & 0.629 & 0.737 \\
S3 - Environmental valuation & 15.5319 & 7.780 & 0.727 & 0.702 \\
S4 - Corporate value & 15.5479 & 8.174 & 0.653 & 0.728 \\
S5 - Budget support & 15.6436 & 8.220 & 0.618 & 0.739 \\
\hline
\end{tabular}

Based on the results seen in Table 5, it can be seen that the value of $r$ count $>r$ table value at df $(144-2)=0.137$, the value is higher than the entire value of the corrected item-total correlation. Thus, it can be stated that all questions on the indicators $\mathrm{S} 1$, S2, S3, S4, and S5 are all valid or able to reveal values validity measured by the questionnaire, so that it can be used for further analysis.

\subsection{Results of the Structural Equation Model}

This stage evaluates the coefficients or parameters that show the relationship of the influence of one latent variable to another latent variable. The detailed path coefficient presentation is presented in the following table.

Table 6

Results of Analysis of Structural Models of Inter-Variable Relations

\begin{tabular}{|c|c|c|c|c|c|c|}
\hline Variable & Variable & & Estimates & $\begin{array}{c}\text { T value } \\
\text { (Critical } \\
\text { Ratio) } \\
\end{array}$ & p-value & Information \\
\hline $\begin{array}{l}\text { Technological } \\
\text { Characteristics }\end{array}$ & $\begin{array}{l}\text { Structural } \\
\text { Engagement }\end{array}$ & Group & 0.177 & 2.405 & 0.016 & Significant \\
\hline $\begin{array}{l}\text { Organizational } \\
\text { Encouragement }\end{array}$ & $\begin{array}{l}\text { Structural } \\
\text { Engagement }\end{array}$ & Group & 0.359 & 2.389 & 0.017 & Significant \\
\hline Quality of Collaboration & $\begin{array}{l}\text { Structural } \\
\text { Engagement }\end{array}$ & Group & 0.053 & 1.505 & 0.132 & $\begin{array}{l}\text { Not } \\
\text { significant }\end{array}$ \\
\hline $\begin{array}{l}\text { Technological } \\
\text { Characteristics }\end{array}$ & GSCM Implementation & & 0.134 & 2.214 & 0.027 & Significant \\
\hline $\begin{array}{l}\text { Organizational } \\
\text { Encouragement }\end{array}$ & GSCM Implementation & & 0.330 & 2.474 & 0.013 & Significant \\
\hline Quality of Collaboration & GSCM Implementation & & 0.063 & 2.039 & 0.041 & Significant \\
\hline $\begin{array}{l}\text { Structural } \quad \text { Group } \\
\text { Engagement }\end{array}$ & GSCM Implementation & & 0.188 & 1.968 & 0.049 & Significant \\
\hline
\end{tabular}


The coefficient of influence of technological characteristics (X1) on the structural group engagement (Y1) is 0.177 with a $t$ value of 2.405. The coefficient shows that the technology characteristic variable (X1) has a positive effect on the structural group engagement (Y1). This means that an increase in technological characteristics (X1), will be followed by an increase in the structural group engagement (Y1), assuming other factors that affect the size of the involvement of the structural group engagement (Y1) are considered constant. Statistical values t calculate the effect of technological characteristics (X1) on the structural group engagement (Y1) of 2.405, with a probability value of 0.016 . This means that technological characteristics (X1) have a positive and significant effect on the structural group engagement (Y1).

The effect coefficient of the technological characteristics (X1) on GSCM implementation (Y2) is 0.134 with a $\mathrm{t}$ value of 2.214. The coefficient shows that the technological characteristics (X1) has a positive effect on GSCM implementation (Y2). This means that an increase in technological characteristics (X1), will be followed by an increase in GSCM implementation (Y2), assuming other factors that affect the size of the GSCM implementation (Y2) are considered constant. The statistical value t calculates the effect of technological characteristics (X1) on the GSCM (Y2) implementation of 2, 214, with a probability value of 0.027 . This means that technological characteristics (X1) have a positive and significant effect on GSCM implementation (Y2).

The coefficient of influence of the organizational encouragement (X2) on the structural group engagement (Y1) is 0.359 with a $\mathrm{t}$ value of 2.389. The coefficient shows that the organizational encouragement (X2) has a positive effect on the structural group engagement (Y1). This means that an increase in organizational encouragement (X2), will be followed by an increase in the structural group engagement (Y1), assuming other factors that influence the size of the structural group engagement (Y1) are considered constant. The statistical value t counts the influence of organizational encouragement (X2) on the structural group engagement (Y1) of 2,389 , with a probability value of 0.017 . This means the organizational encouragement (X2) has a positive and significant effect on the structural group engagement (Y1).

The coefficient of influence of the organizational encouragement (X2) on GSCM implementation (Y2) is 0.330 with a t value of 2.474. The coefficient shows that the organizational encouragement (X2) has a positive effect on GSCM implementation (Y2). This means that an increase in organizational encouragement (X2), will be followed by an increase in GSCM implementation (Y2), assuming other factors that affect the size of the GSCM implementation (Y2) are considered constant. The statistical value $t$ counts the influence of the organizational encouragement (X2) on GSCM implementation (Y2) of 2.474, with a probability value of 0.013. This means the organizational encouragement (X2) has a positive and significant effect on GSCM implementation (Y2).

The coefficient of influence of the quality of collaboration (X3) on the structural group engagement (Y1) is 0.053 with a $t$ value of 1.505. The coefficient shows that the quality of collaboration (X3) is positive towards the structural group engagement (Y1). Statistical values t calculate the effect of the quality of collaboration (X3) on the structural group engagement (Y1) of 1.505, with a probability value of 0.132 . This means that the quality of collaboration (X3) does not significantly influence the structural group engagement (Y1).

The coefficient of influence of the quality of collaboration (X3) on GSCM implementation (Y2) is 0.063 with a t value of 2.039. The coefficient shows that the quality of collaboration (X3) has a positive effect on GSCM implementation (Y2). This means that the improvement of the quality of collaboration (X3), will be followed by an increase in GSCM implementation (Y2), assuming other factors that affect the size of GSCM implementation (Y2) are considered constant. Statistical values t calculate the effect of quality of collaboration (X3) on GSCM implementation (Y2) of 2.039, with a probability value of 0.041 . This means that quality of collaboration (X3) has a positive and significant effect on GSCM implementation (Y2).

The variable influence coefficient of the structural group engagement (Y1) on GSCM implementation (Y2) is 0.188 with a $t$ value of 1.968. The coefficient shows that the structural group engagement (Y1) has a positive effect on GSCM implementation (Y2). This means that increasing the structural group engagement (Y1) will be followed by an increase in GSCM implementation (Y2), assuming other factors that affect the size of the GSCM implementation (Y2) are considered constant. The statistical value $t$ counts the influence of the structural group engagement (Y1) on the GSCM implementation (Y2) of 1.968, with a probability value of 0.049. This means that the involvement of the structural group engagement (Y1) has a positive and significant effect on GSCM implementation (Y2).

\section{CONCLUDING REMARKS}

Statistical results show that the technological characteristics have a significant effect on increasing the structural group engagement. As an extrinsic factor, the characteristics of green technology that suit the needs of mining companies will have an impact on increasing the structural group engagement. Technological characteristics have a strong influence on improving GSCM implementation. The results of this study explain that all indicators plays an important role in improving the quality of GSCM implementation.

The organizational encouragement affects the direct involvement of the structural group engagement. PT Vale Indonesia and PT Agincourt Resources make the role of the organizational encouragement very strategic so that the GSCM concept is realized by involving leaders from all divisions and structural levels. Increased organizational encouragement statistically has a strong influence 
on improving GSCM implementation. All indicators from organizational encouragement proved to be able to improve GSCM implementation.

The quality of collaboration does not have a significant effect on increasing the structural group engagement, this is due to the low teamwork in the work environment which will reduce the productivity of the company. There are obstacles in the team, these obstacles are in the form of low cooperative attitude. The quality of collaboration has a strong influence on improving GSCM implementation. The results of this study explain that all indicators in the quality of collaboration. Statistical results show the magnitude of the influence of the structural group engagement on GSCM implementation.

\section{REFERENCES}

[1] Chin, Thoo Ai., Huam Hon Tat, \& Zuraidah Sulaiman. (2015). Green Supply Chain Management, Environmental Collaboration and Sustainability Performance. Procedia CIRP, 26 (2015) 695 - 699.

[2] Singh, A., \& A. Trivedi. (2016). Sustainable green supply chain management: trends and current practices. Competitiveness Review, Vol. 26 Issue: 3, pp.265-288.

[3] Solomon, C., Mohamad, M. N., \& Jamaluddin, R. (2014). Development in corporate sustainability: the green supply chain management perspective and challenges. Journal of Asian Scientific Research, 2014, 4(10): 590-596.

[4] Kafa, N., Y. Hani, A. El Mhamedi. (2013). Sustainability Performance Measurement for Green Supply Chain Management. IFAC Proceedings Volumes, Vol. 46, Issue 24, pp: 71-78.

[5] Seman, N. A. A., Zakuan, N., Jusoh, A., Arif, M. S. M., \& Saman, M. Z. M. (2012). Green supply chain management: a review and research direction. International Journal of Managing Value and Supply Chains, 3(1), 1-18.

[6] Halldorsson, A., \& M. Svanberg (2013). Energy resources: trajectories for supply chain management. Supply Chain Management: An International Journal, Vol. 18 Issue: 1, pp.66-73.

[7] Fang, C., \& J. Zhang. (2018). Performance of green supply chain management: A systematic review and meta analysis. Journal of Cleaner Production, Volume 183, 10 May 2018, Pages 1064-1081.

[8] Luthra, S., Kumar, V., Kumar, S., \& Haleem, A. (2011). Barriers to implement green supply chain management in automobile industry using interpretive structural modeling technique: An Indian perspective. Journal of Industrial Engineering and Management, 4(2), 231-257.

[9] Bice, S. (2011). On the Radar? Gendered Considerations in Australia-Based Mining Companies' Sustainability Reporting, 2004-2007. Gendering the field: towards sustainable, 145.

[10] Mallidis, I., \& Vlachos, D. (2010). A Framework for green supply chain management. In 1st Olympus international conference on supply chain (pp. 1-2).

[11] Pesch, M. J., Murphy, R. T., \& Ahmad, S. (2012). Murphy Warehouse Company. Journal of the International Academy for Case Studies, 18(3), 125.

[12] Levashova, Y., Jonkers, I., Lambooy, T (2010) Biodiversity: Business and Finance. Nyenrode Business Universiteit.

[13] Wang, Y., Lin, W., \& Wan, Q. (2012). Green Growth: Constructing a Resource-Saving and Environment-Friendly Production Pattern. In China Green Development Index Report 2011 (pp. 31-48). Springer Berlin Heidelberg.

[14] Oxford Dictionary (2013) Green Technology. https://en.oxforddictionaries.com/definition/green_technology

[15] Li, Y. (2011). Research on the performance measurement of green supply chain management in China. Journal of Sustainable Development, 4(3), 101.

[16] Lin, C. Y., \& Ho, Y. H. (2008). An empirical study on logistics service providers' intention to adopt green innovations. Journal of Technology Management \& Innovation, 3(1), 17-26.

[17] Hu, A. H., \& Hsu, C. W. (2010). Critical factors for implementing green supply chain management practice: an empirical study of electrical and electronics industries in Taiwan. Management research review, 33(6), 586-608.

[18] Tseng, M. L. (2011). Green supply chain management with linguistic preferences and incomplete information. Applied Soft Computing, 11(8), 4894-4903.

[19] Pullig, C., Maxham, J. G., \& Hair, J. F. (2002). Salesforce automation systems: An exploratory examination of organizational factors associated with effective implementation and salesforce productivity. Journal of Business Research, 55(5), 401-415.

[20] Kock, A., Heising, W., \& Gemünden, H. G. (2015). How Ideation Portfolio Management Influences Front-End Success. Journal of Product Innovation Management, 32(4), 539-555.

[21] Bhatti, Z. A., Baile, S., \& Yasin, H. M. (2011). The success of corporate wiki systems: an end user perspective. In Proceedings of the 7th International Symposium on Wikis and Open Collaboration (pp. 134-143). ACM.

[22] Heimeriks, K., \& Schreiner, M. (2002). Alliance capability, collaboration quality, and alliance performance: an integrated framework. Eindhoven Center for Innovation Studies, Eindhoven, 31-49.

[23] Josiam, B. M., Smeaton, G., \& Clements, C. J. (1999). Involvement: Travel motivation and destination selection. Journal of Vacation Marketing, 5(2), 167-175.

wWW.scirj.org

(C) 2019, Scientific Research Journal

http://dx.doi.org/10.31364/SCIRJ/v7.i2.2019.P0219616 
[24] Chan, R. Y., He, H., Chan, H. K., \& Wang, W. Y. (2012). Environmental orientation and corporate performance: The mediation mechanism of green supply chain management and moderating effect of competitive intensity. Industrial Marketing Management, 41(4), 621-630. 